Оригинални научни рад

Dmitriy Galushko, Ph.D., Associate Professor

Voronezh State University, Russia

Department of Law

\title{
SOME ASPECTS OF HARMONIZATION OF THE EU CUSTOMS LAW AND THE CUSTOMS LAW OF THE CUSTOMS UNION OF RUSSIA, BELARUS AND KAZAKHSTAN
}

Abstract: this paper aims at analyzing of the possible ways of harmonization of the EU legal norms and norms of the newly created Customs Union of Russia, Belarus and Kazakhstan as one of the outcomes of the process of Eurasian integration. First, the author examined the process of adoption of the legal basis for functioning of the Customs Union, then, these legal norms were analyzed in the light of the EU law, and finally, the author sets some ways for harmonization between two legal orders, particularly through the procedure of transit.

Key words: Customs Union of Russia, Belarus and Kazakhstan, the European Union, harmonization, approximation, Eurasian Integration.

The Partnership and Cooperation Agreement between Russia and the EU of 1994 has included the approximation of legislation of the parties in the customs sector and the sector of foreign trade. The most important prerequisite for such approximation for the European Union is the fact that its own customs legislation has been substantially harmonized and unified long time ago.

Harmonisation of the Russian legislation with the EU customs and trade law is very justified for the Russian Federation. The European Union is the largest trading partner for Russia, taking $52 \%$ of the total trade turnover. In turn, Russia is the third largest trading partner for the EU after the United States and China ${ }^{1}$.

1 See for example: URL: http://eeas.europa.eu/delegations/russia/documents/news/ 20120601_2_eurostat_ru.pdf 
On October 6, 2007 Belarus, Kazakhstan and Russia signed a Treaty establishing the single customs territory and the establishment of the Customs Union $^{2}$.

In accordance with Art. 1 of the Treaty 2007, the Customs Union is a form of integration, providing the single customs territory, consisting of the customs territories of its participants. Within this area on trade of products, originating from a single customs territory, as well as originating from the third countries, but released for free circulation in that territory, customs duties and restrictions of economic nature will not apply with the exception of special protective, antidumping and countervailing measures.

On November 27, 2007 there were approved: a) List of International treaties, that form the legal framework of the Customs Union, and b) Plan of action for formation of the Customs Union within the Eurasian Economic Community ${ }^{3}$.

The Action Plan includes seven groups of activities for the formation of the Customs Union. These documents are based on the same principles as the customs union within the European Union.

In parallel with the formation of the international basis of the Customs Union, modernization of Russian customs law and of customs infrastructure was taking place. Thus, on July 9, 2009 the State Border Committee of the Russian Federation approved the Concept of customs clearance and customs control of goods in places close to the state border of the Russian Federation ${ }^{4}$. The concept should be the main provisions of the International Convention on the Simplification and Harmonization of Customs Procedures signed on May 18, 1973 (as amended by Protocol of June 26, 1999). . It involves the use of prior information and its transmission in electronic form, as well as the Framework of Standards of Securing and Facilitating of Global Trade of $2005^{6}$. The concept defines the purpose, key objectives and priority activities for organization of customs clearance and customs control at locations close to the state border of the Russian Federation up to 2020.

At the same time, development of the international legal vehicle was also continuing. So, on November 27, 2009, the Common Customs Tariff of the $\mathrm{Cu}-$

2 Договор о создании единой таможенной территории и формировании таможенного союза (Душанбе, 6 октября 2007 г.) // Бюллетень международных договоров. - Июль 2011 г. - № 7.

3 Решение Межгосударственного Совета ЕврАзЭС от 27.11.2009 № 14.

4 URL: http://www.customs.ru/index.php?option=com_content\&view=article\&id=8016 \&Itemid $=1874$.

5 Международная конвенция об упрощении и гармонизации таможенных процедур от 18 мая 1973 года (в ред. Протокола от 26 июня 1999 г.) // Собрание законодательства РФ. - 08.08.2011. - № 32. - Ст. 4810.

6 Рамочные стандарты безопасности и облегчения мировой торговли 2005 г. 
stoms Union was approved ${ }^{7}$ by the Member States. Thus, the Member States of the Customs Union share the common customs tariff (CCT) and other common measures regulating trade with third countries. The CCT includes a set of customs duties applied to goods imported to the common customs area from third countries, classified in accordance with the Single Commodity Nomenclature for Foreign Economic Affairs.

Finally, on November 27, 2009 the Customs Code of the Customs Union was approved in the form of an international treaty ${ }^{8}$. The Code was to come into force on July 1, 2010. However, on April 16, 2010 (i.e. before the entry into force) the special Protocol made significant changes to the document. Therefore, the Customs Code went into effect on July 1, 2010 in a new edition.

On July 5, 2010 the Protocol on certain temporary exemptions from the regime of operation of a single customs territory of the Customs Union was approved by the Member States ${ }^{9}$. The Treaty on the Customs Code will apply subject to the provisions of the Protocol of July 5, 2010. So, the new version of the Code is valid from July 6, 2010 in all three Member States of the Customs Union.

The provisions of the Code of the Customs Union since its entry into force have the force of international agreement and are directly applicable in the participating countries primarily over the rules of national customs legislation. Such scheme has been taken from the EU customs union.

Today, the Customs Union is working in conditions where preparation of the regulatory framework is not yet fully completed.

The legislation of the Customs Union affects not only the internal order of movement of goods between the Member States, but it fundamentally changes the customs relations with all other countries. At the moment, the legal system of the Customs Union consists of international and municipal norms. The norms of international law include: a) the Customs Code, and b) international agreements adopted by the Member States in accordance with the Code, c) decisions of the Commission of the Union. International standards contain many references to the legislation of the states.

Norms of municipal law include: a) laws on customs regulations, and b) delegated legal acts adopted by national authorities, c) regulations of national customs authorities.

7 Единый таможенный тариф Таможенного союза Республики Беларусь, Республики Казахстан и Российской Федерации (ЕТT) (Утвержден в г. Минске 27.11.2009 Решением N 18 Межгосударственного Совета Евразийского экономического сообщества, Решением N 130 Комиссии Таможенного союза).

8 Таможенный кодекс Таможенного союза (приложение к Договору о Таможенном кодексе Таможенного союза, принятому Решением Межгосударственного Совета ЕврАзЭС на уровне глав государств от 27.11.2009 №17) (ред. от 16.04.2010).

9 Протокол об отдельных временных изъятиях из режима функционирования единой таможенной территории Таможенного союза (Подписан в г. Астане 05.07.2010). 
The conceptual basis of the already established and developing customs legislation consists of provisions of the Convention on the Simplification and Harmonization of Customs Procedures, concluded at Kyoto in $1973^{10}$. The members of the Kyoto Convention are almost all leading nations of the world and the European Union. Generally accepted international rules and principles are also taken into account, including the provisions of the legal system of the World Trade Organization, the Convention on common transit procedure of $1987^{11}$, the Convention between the European Economic Community and the Republic of Austria, the Republic of Finland, the Republic of Iceland, the Kingdom of Norway, the Kingdom of Sweden and the Swiss Confederation on the simplification of formalities in trade of goods of $1987^{12}$. Approximation of the customs legislation with international standards is also dictated by the desire of the three Member States quicker complete the negotiations on accession to the World Trade Organization.

In 2010 the Russian Federation adopted the Federal Law "On Customs Regulation in the Russian Federation"13. The law is in full compliance with the $\mathrm{Cu}$ stoms Code. Its provisions are based on global practices, including the Kyoto Convention, taking into account the modern trends of development of customs and customs tariff policy, direction of the Russian Federation on the facilitation of exports of high technology products and acceleration of customs operations. The law provides for the organizational functioning of the Russian Customs Service and governs issues not reflected in the Customs Code.

On May 19, 2011 Member States signed the Treaty on the functioning of the Customs Union within the framework of the multilateral trading system ${ }^{14}$, taking into account the entry to the WTO. Since July 1, 2011 internal borders of the Union became fully open.

Thus, inside the Union customs control is fully lifted. But customs control has been fully preserved along the outer perimeter of the territory of the $\mathrm{Cu}$ stoms Union. Customs Services of Russia, Belarus and Kazakhstan share basic information on each consignment to be drawn up in their territory. Information exchange and other forms of interaction in conditions of the single customs space allows to respond to emerging risks.

10 Международная конвенция об упрощении и гармонизации таможенных процедур (Киотская конвенция) (Заключена в г. Киото 18.05.1973) (с изм. и доп. от 26.06.1999).

11 Конвенция о процедуре общего транзита 1987 г. // OJ L 226, 13.8.87.

12 Convention on the simplification of formalities in trade in goods. URL: http://ec.europa.eu/taxation_customs/resources/documents/sad-convention_on_simplification_of_formalities_en.pdf

13 Федеральный закон от 27.11.2010 N 311-Ф3 "О таможенном регулировании в Российской Федерации" // Собрание законодательства РФ. - 2010. - № 48. - Ст. 6252.

14 Договор о функционировании Таможенного союза в рамках многосторонней торговой системы (Подписан в г. Минске 19.05.2011). 
Customs services of the three Member States have taken a set of measures for smooth transition to the new legislation. The adoption of legislative acts in the field of customs affairs at the national level is justified by the need to restrict the domestic market from import competition by protectionist measures and to help to promote export of domestic products to foreign markets. Regarding to the international level of the customs sphere, the same questions should be considered, but in the light of international customs integration and international relations of the Customs Union. And here, all projects to reform the existing models of cooperation in customs matters are reduced to two extremes - either to repeating, almost to verbatim quotation of the Convention on the simplification and harmonization of customs procedures, or to compiling of national codes.

Sometimes, it is also noted the importance of the orientation of the main provisions of the new customs legislation, in other words - what are the nature of the measures of customs regulation of international trade? Economic or administrative? Current provisions of the customs legislation of the Customs Union are based mainly on prescriptive (administrative) method. The European Union mainly uses dispositive method of customs law that makes possible to select the subjects of customs legal behaviors within acceptable conditions.

The text of the Customs Code reflects many of the institutions of the EU customs law. Analysts say that the International customs law is constantly responding to changing conditions of international markets, and the rules, that allow customs authorities to cope with the rapidly changing challenges, operationally includes to the EU customs legislation. The use of EU experience in the development of the Customs Union is quite reasonable. The First Deputy Prime Minister Igor Shuvalov said, that "intensifying cooperation of the Customs Union and the EU, the European Union will create a new framework for development. We will try to pave the bridges for the overall economic interests of the EU, of the Customs Union to the interests that are most important to the AsiaPacific region" ${ }^{15}$.

One of these bridges can be a transit of goods to or from the EU through the territory of the Customs Union of Russia, Belarus and Kazakhstan. Legal regulation of the institute of international transit is provided by the Customs Code and, in many ways, influenced by the European Union law.

In general, changes in the customs transit procedure in accordance with the Code, compared to previously effective national customs legislation of the Member States, seem to be positive. The legislator led to uniformity in the conceptual apparatus, having reduced time of the processing of documents by the customs authorities, the order of presentation of goods to customs has also become easier. Thus, the tendency of unification of the laws of the three countries

15 URL: http://www.sovet-ts.ru/novosti/novost_odin. 
has been ensured. New rules are designed to simplify and facilitate control by the customs offices, thereby reducing the number of administrative barriers for goods in transit. Due to the transit of goods, mutual beneficial economic relations between the Member States of the Customs Union, the Commonwealth of Independent States and the EU countries have been accelerated.

In principle, the direct distribution of the EU transit procedures for the territory of the customs union is possible in two ways:

First - accession of the Member States to the EU. In the foreseeable future, this option seems unlikely.

Second - the Member States' accession to the Convention on a common transit procedure. But they must first obtain the consent of all participants of the Treaty (members of the EU, Iceland, Norway and Switzerland in the Joint Committee, which shall invite the States to sign the Convention). This option is more realistic.

However, within the Customs Union it is likely to create conditions for the normal functioning of the common transit in advance. In this regard, it is advisable to conduct series of measures.

First, it seems appropriate to develop the legal conditions for the establishment of comprehensive centers for joint implementation of customs control and the possibility of putting into practice of the principle of the "single window" at the national level to facilitate the processing of all transit-related documents in one place. Second, it seems reasonable to continue to work towards a unified automated information system of customs transit control between the Member States of the Customs Union.

When creating a uniform automated information system of customs transit control, the Member States of the Customs Union are to be implemented the following principles:

- using a harmonized list of information and format of their submission for the exchange of information between the customs services of the Member States;

- ensuring interoperability with the new computerized transit system of the EU countries (NCTS);

- obtaining of information about goods and vehicles transported under customs control in real time by customs authorities of the Union.

The mutual recognition of customs documents by the EU and the Member States of the Customs Union is also needed.

After removing all the obstacles it seems to be possible to refuse customs inspections at the border for transport from the EU. Initially simplified procedure can be applied to persons authorized by the customs authorities of the EU to use simplified transit procedures. During the transition period, the Russian customs authorities will be able to determine the range of carriers, which are the 
first to be able to use the simplified procedure of transportation without customs inspection.

As a "pilot project" before the introduction of procedures for transit across the Customs Union it is possible to implement its use only in the territory of the Kaliningrad region, which requires an interim agreement between the EU and Russia. However, this measure will partially ease the transportation of goods through the territory of Lithuania due to the lack of need for customs clearance at the border of Lithuania and the Kaliningrad region.

After the transition period transit procedure shall apply for all carriers. The customs authorities may selectively continue to inspect cargo, depending on the availability of information on the alleged violation, or by using risk analysis of violations.

After the complete unification of documents and customs clearance procedures, the unified transit system (EU-Russia) can be created. For reliable operation of this procedure in the Customs Union a system similar to the New Computerized Transit System in the EU should be used for customs clearance. In this case the customs authorities of the EU and Russia should be able to communicate directly with each other (as within the EU).

Legal aspects of the relationship of customs services in the creation and functioning of the unified system of customs transit control should be reflected in the respective intergovernmental agreements.

In conclusion, it should be noted that the establishment of the Customs Union of Belarus, Kazakhstan and Russia is one of the first steps in the process of Eurasian integration and of possible creation of the Eurasian Economic Union. The Member States take into account the world experience of the integration process, and in this regard, the experience of the EU is particularly noteworthy. Despite some problems and criticism of the model of the European Union, one of the main elements of the EU - the Customs Union - works extremely efficiently.

The legislation of the Customs Union has adapted some of the provisions of the customs legislation of the European Union, unifying some of the measures and, in some cases, providing an indirect application of the EU law. However, at present it is not enough for proper regulation of public relations in the customs sphere, especially in the field of customs transit. Therefore, work of the Member States of both integration entities should develop in this direction on a bilateral mutually beneficial basis. 
Др Дмитириј Галушко, ванредни ирофесор Државни Универзииетеи Вороњеж, Русија

Правни факулиетеи

\section{Поједини аспекти хармонизације царинског права ЕУ и царинског права Царинске уније Русије, Белорусије и Казахстана}

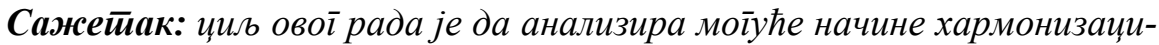
је ирравних норми ЕУ и норми новоформиране Царинске уније Русије, Бело-

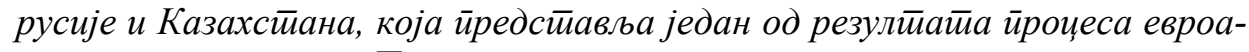

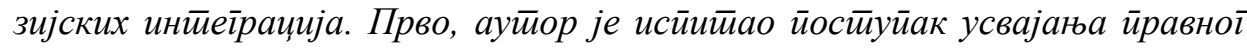
основа за функиионисање иаринске уније, затиим су ове иравне норме анализиране у светлу иррава ЕУ и на крају, ауйор износи одређене начине хар-

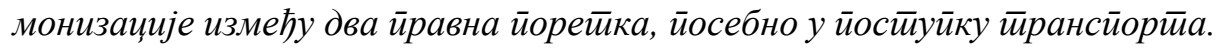

Кључне речи: Царинска унија Русије, Белорусије и Казахстиана, Евройска унија, хармонизачија, уједначавање, евроазијска иниееіраиија. 